\title{
Distinct, Gene Specific Effect of Heat Shock on Heat Shock Factor-1 Recruitment and Gene Expression of CXC Chemokine Genes
}

\author{
Tapan K. Maity ${ }^{1}$, Michael M. Henry ${ }^{1}$, Mohan E. Tulapurkar ${ }^{1}$, Nirav G. Shah ${ }^{1}$, Jeffrey D. \\ Hasday 1,2,3,4, and Ishwar S. Singh ${ }^{1,2,4}$ \\ ${ }^{1}$ Division of Pulmonary and Critical Care, Department of Medicine, University of Maryland School \\ of Medicine, Baltimore, Maryland, USA \\ ${ }^{2}$ Mucosal Biology Research Center, University of Maryland School of Medicine, Baltimore, \\ Maryland, USA \\ ${ }^{3}$ Cytokine Core Laboratory, University of Maryland School of Medicine, Baltimore, Maryland, USA \\ ${ }^{4}$ Research Services of the Baltimore VA Medical Center, Baltimore, Maryland, USA 21201.
}

\begin{abstract}
The heat shock (HS) response, a phylogenetically conserved ubiquitous response to stress, is generally characterized by the induced expression of heat shock protein (HSP) genes. Our earlier studies showed that the stress-activated transcription factor, heat shock factor-1 (HSF1), activated at febrile range or HS temperatures also modified expression of non-HSP genes including cytokine and chemokine genes. We also showed by in silico analysis that 28 among 29 human and mouse CXC chemokine genes had multiple putative heat shock response elements (HSEs) present in their gene promoters. To further determine whether these potential HSEs were functional and bound HSF1, we analyzed the recruitment of HSF1 to promoters of 5 human CXC chemokine genes (CXCL-1, 2, 3, 5 and 8) by chromatin immunoprecipitation (ChIP) assay and analyzed the effect of HS exposure on tumor necrosis factor- $\alpha(\mathrm{TNF} \alpha)$-induced expression of these genes in human lung epithelial-like A549 cells. HSF1 ChIP analysis showed that HSF1 was recruited to all but one of these CXC chemokine genes (CXCL-3) and HS caused a significant increase in recruitment of HSF1 to one or multiple HSEs present in the promoters of CXCL-1, 2, 5 and 8 genes. However, the effect of HS exposure on expression of these genes showed a variable gene-specific effect. For example, CXCL8 expression was markedly enhanced ( $\mathrm{p}<0.05$ ) whereas CXCL5 expression was significantly repressed $(\mathrm{p}<0.05)$ in cells exposed to HS coincident with TNF $\alpha$ stimulation. In contrast, expression of CXCL1 and CXCL2, despite HSF1 recruitment to their promoters, was not affected by HS exposure. Our results indicate that some, if not all, putative HSEs present in the CXC chemokine gene promoters are functional and recruit HSF1 in vivo but the effects on gene expression are variable and gene specific. We speculate, the physical proximity and interactions of other transcription factors and co-regulators with HSF1 could be critical to determining the effects of HS on the expression of these genes.
\end{abstract}

(C) 2010 Elsevier Ltd. All rights reserved.

Corresponding Author: Ishwar S. Singh, PhD., University of Maryland School of Medicine, Health Science Facility-2, Rm. S311, 20 Penn St. Baltimore, MD 21201, Phone: 410-706-5507, FAX: 410-706-5508, isingh@umaryland.edu.

Publisher's Disclaimer: This is a PDF file of an unedited manuscript that has been accepted for publication. As a service to our customers we are providing this early version of the manuscript. The manuscript will undergo copyediting, typesetting, and review of the resulting proof before it is published in its final citable form. Please note that during the production process errors may be discovered which could affect the content, and all legal disclaimers that apply to the journal pertain. 


\section{Keywords}

Hyperthermia; stress; TNF; A549; IL-8; transcription

\section{Introduction}

The heat shock (HS) response is an ubiquitous and phylogenetically conserved response that protects cells against a myriad of physical and chemical stresses [1-5]. It is generally characterized by a shift in the transcriptional program resulting in the induced expression of a set of evolutionarily conserved heat shock protein (HSP) genes that preserve cell viability by sequestering denatured cellular proteins and facilitating their refolding or degradation. Expression of HSP genes is regulated by the stress-activated transcription factor, heat shock factor-1 (HSF1), which binds to cis-acting heat shock response elements (HSEs) comprising inverted triad/dyad nGAAn repeats [6-8]. Activation of HSF1 following stress is a complex multi-step process comprising trimerization, nuclear translocation, acquisition of DNA binding activity, and transactivation of responsive genes [8,9]. Trimerization of HSF1 directly confers DNA-binding capacity but transactivation requires subsequent modifications that include phosphorylation and sumoylation [10-12]. Although identified as an activator of HSP genes, recent studies have indicated an expanding role of HSF1, including its role as a transcriptional regulator of several non-HSP genes, several of which participate in the regulation of inflammatory responses and immune defenses [13-24]. For example, HSF1 mediates HS-induced transcriptional repression of human pro-interleukin (IL)-1 $\beta$, c-fos, urokinase-type plasminogen activator $[13,19,20]$, and TNF $\alpha$ genes $[14,15,17,18,22]$. We found that exposure to febrile-range hyperthermia (FRH) markedly enhanced intrapulmonary expression of the CXC chemokines, KC, LIX and MIP-2 in mouse models of pneumonia and pulmonary oxygen toxicity [23-25] and demonstrated that this phenomenon requires HSF1 [24]. We showed that HSF1 binds to at least two 5 '-flanking regions in the human CXC chemokine, IL-8/CXCL8, gene and that interaction of HSF1 with these CXCL8 promoter sequences augments tumor necrosis factor- $\alpha$ (TNF $\alpha)$-induced activation of IL-8/CXCL8 transcription [24]. Similar effects of HS were also demonstrated for the iNOS gene in which HSF1 binds to the iNos gene promoter and enhances LPSinduced iNos gene expression in heat shocked RAW macrophage cell line [26].

We previously performed a computational analysis of potential HSEs in CXC chemokine 5'flanking sequences that revealed the presence of putative HSE sequences in 28 of 29 human and mouse CXC chemokines [21]. However, the capacity of these promoter sequences to bind HSF1 and the consequences for gene activation have not yet been analyzed. In the present study we extend our previous observations of CXCL8 expression by analyzing the interaction of HSF1 with the human CXC chemokines, CXCL1, CXCL2, CXCL3, and CXCL5 and analyzed the effects of HS on expression of each of these genes.

\section{Materials and methods}

\subsection{Cell culture}

Human pulmonary epithelial-like A549 cells were maintained in RPMI 1640 supplemented with $50 \mathrm{U} / \mathrm{ml}$ penicillin, $50 \mu \mathrm{g} / \mathrm{ml}$ streptomycin, $2 \mathrm{mM}$ L-glutamine, $1 \mathrm{mM}$ sodium pyruvate, $10 \mathrm{mM}$ N-2-hydroxyethylpiperazine-N'-2-ethanesulfonic acid (HEPES) buffer (GIBCO/ Invitrogen, Carlsbad, CA), pH 7.3 (Complete RPMI; CRPMI) and 5\% defined fetal bovine serum (FBS; Hyclone, Logan, UT) as described previously [24]. For analysis of CXC chemokine gene expression, A549 cells were seeded at $0.5 \times 10^{5} / \mathrm{ml}$ in $35 \mathrm{~mm}$ culture dishes and maintained at $37^{\circ} \mathrm{C}$. After 2 days, the cells were stimulated with $1 \mathrm{ng} / \mathrm{ml}$ of human $\mathrm{TNF} \alpha$ and incubated either at $37^{\circ} \mathrm{C}$ or immediately subjected to heat shock at $42^{\circ} \mathrm{C}$ for $2 \mathrm{~h}$ 
followed by incubation at $37^{\circ} \mathrm{C}$. Cells were harvested either immediately after $\mathrm{HS}$ (0h) or 1 , 2 , or $4 \mathrm{~h}$ after $\mathrm{HS}$ for isolation of RNA. Similarly treated non-heat shocked cells at $37^{\circ} \mathrm{C}$ were also harvested at the corresponding time points.

\subsection{Immunoblotting}

A549 cells were lysed in Cell Culture Lysis buffer, resolved on 10\% SDS-polyacrylamide gels, transferred to polyvinylidene fluoride membranes and immunoblotted for HSP72 (rat monoclonal, Santa Cruz) and $\beta$-tubulin (mouse monoclonal, Chemicon) essentially as described earlier $[24,27,28]$.

\subsection{RNA Extraction and quantitative real-time PCR (qRT-PCR)}

Total RNA was isolated using RNeasy Kit (QIAGEN) according to the manufacturer's instructions. Isolated RNA was reverse-transcribed using oligo-dT primers and a cDNA synthesis kit according to the manufacturer's protocol (Promega). Duplicate $25 \mu \mathrm{l}$ real-time PCR reactions were performed in 96 well plates using a SYBR-Green reaction mix (BioRad) in BioRad iCycler (Thermocycler) according to the supplier's protocol. Primer pairs for CXCL-1, 2, 3 and 5 were obtained from SuperArray while primer pairs for CXCL8, HSPA1A and GAPDH were obtained from Realtimeprimers.com. Data were quantified using the gene expression Ct difference method as described by Schefe et al. [29] and standardized to levels of the housekeeping gene, GAPDH using Ct values automatically determined by the thermocycler. Efficiency of amplification for each primer pair was calculated and data analyzed essentially as descried earlier [17,24,27].

\subsection{Chromatin Immunoprecipitation (ChIP) Assay}

ChIP assays were performed using a kit from Millipore according to the manufacturer's protocol as we have previously described $[15,18,24]$. Briefly, A549 cells were heat shocked at $42^{\circ} \mathrm{C}$ for $1 \mathrm{~h}$ and fixed by adding formaldehyde (Sigma, St. Louis, MO) to the medium to a final concentration of $1 \%$. After 15 min the cells were washed, resuspended in SDS lysis buffer and sonicated. Immunoprecipitation was carried out at $4^{\circ} \mathrm{C}$ overnight using $2 \mu \mathrm{g}$ antiHSF-1 rabbit polyclonal antibody or non-immune rabbit IgG as a control (both from SantaCruz) and immune complexes were washed, eluted, and protein-DNA cross linking was reversed according to the manufacturer's protocol. Immunoprecipitated DNA was quantified by qRT-PCR using primer pairs spanning the HRE consensus sequence for the respective genes (Table 1) as described earlier [18]. qRT-PCR data was analyzed using a template from SA Biosciences, and fold enrichment with specific anti-HSF1 antibody against non-specific rabbit polyclonal antibody was determined [18].

\subsection{ELISA for analysis of CXCL8 and CXCL5 production}

IL-8 (CXCL8) and ENA 78 (CXCL5) production was measured by ELISA essentially as described earlier [24]. Briefly, A549 cells were plated in 24-well culture plates at 5.0 $\times 10^{4}$ cells $/ \mathrm{ml} /$ well $24 \mathrm{~h}$ before stimulation with TNF $\alpha$. Cells were stimulated with recombinant human TNFa (R \& D Systems; Minneapolis, MN) for $15 \mathrm{~min}$ at $37^{\circ} \mathrm{C}$ and then either were incubated at $37^{\circ} \mathrm{C}$ for an additional $6 \mathrm{~h}$ (control) or were heat-shocked by incubating for $2 \mathrm{~h}$ at $42^{\circ} \mathrm{C}$ then returned to $37^{\circ} \mathrm{C}$ for an additional $4 \mathrm{~h}$. IL-8 and ENA 78 concentration in culture supernatants was measured in the University of Maryland Cytokine Core Lab by ELISA using paired antibodies from R \& D Systems (Minneapolis, MN). The lower detection limit for these assays were 3.9 and $15 \mathrm{pg} / \mathrm{ml}$, respectively.

\subsection{Statistical analysis}

Data are presented as mean \pm standard error (SE). Differences between two groups were tested using an unpaired Student t-test. Differences among more than two groups were 
analyzed by applying a Tukey Honestly Significant Difference test to a one-way analysis of variance (ANOVA). Differences in chemokine gene expression levels over time between heat-shocked and control cells were analyzed by Multivariate analysis of variance (MANOVA). Differences with $\mathrm{p}<0.05$ were considered significant.

\section{Results}

\subsection{HS activates HSF1 and induces HSP72 expression in A549 cells}

We analyzed the effects of HS on CXC chemokine gene expression in human pulmonary epithelial-like A549 cells, in which we previously demonstrated augmented CXCL8 expression following HS. To confirm that the HS protocol used in this study stimulated a significant HS response, we exposed the cells to HS and analyzed activation of HSF1 and induction of HSP72 gene expression. HSF1-ChIP assays showed that exposing A549 cells at $42^{\circ} \mathrm{C}$ for 60 min increased the recruitment of HSF1 to the HSP72 chromatin by approximately 14-fold compared with non-heat shock control cells (Fig 1a). To analyze the induction of HSP72 expression, A549 cells were heat shocked at $42^{\circ} \mathrm{C}$ for $2 \mathrm{~h}$, then switched to $37^{\circ} \mathrm{C}$ and total RNA was prepared either immediately after completion of the HS exposure (0h) or after a 1, 2 or $4 \mathrm{~h}$ recovery. To analyze HSP72 protein expression, A549 cells were heat shocked for $2 \mathrm{~h}$, recovered at $37^{\circ} \mathrm{C}$ for $4 \mathrm{~h}$ and cell extracts analyzed for HSP72 protein by immunoblotting. As expected, HS caused an 80-100-fold increase in HSP72 mRNA (Fig 1b) and a 5-fold increase in HSP72 protein (Fig 1c) compared with nonheat shocked control cells.

\subsection{HS recruits HSF1 to CXC chemokine gene promoters in A549 cells}

We have previously shown that the genes of several CXC chemokines including CXCL1, CXCL2, CXCL3, CXCL5, and CXCL8 contain multiple putative HSE sequences in their 5'flanking sequences [21]. To test whether these HSE sequences were functional, we analyzed HS-induced recruitment of HSF1 to the HSE-containing regions of each of these genes using ChIP assays. This analysis showed that some of the HSEs were nonfunctional, but that HSF1 was recruited to at least one of the HSE-containing promoter regions in all but one of these CXC chemokine genes. The CXCL1 gene contains six putative HSE sequences distributed within four 5'-flanking regions, -873/-723 (1 HSE), -676/-551 (3 HSEs), $-300 /-185$ ( 1 HSE) and $-177 /-19$ (1 HSE) (see Table 1). Of the four regions analyzed by ChIP, only the $-175 /-19$ region exhibited significant HS-induced HSF1 recruitment (Fig 2a). In the case of CXCL2 gene promoter, which also contained six HSEs distributed within four regions of the 5'-flanking sequence, only regions $-371 /-212$ and $-88 /+41$ (each containing 1 HSE) exhibited significant HS-induced HSF1 recruitment (Fig 2b). In contrast, exposure to HS did not induce HSF1 recruitment to any of the four 5'-flanking regions of CXCL3, which contain five putative HSE sequences. However, both of the two putative HSE-containing 5'-flanking regions in CXCL5 exhibited significant HS-induced HSF1 (Fig 2d). Finally, as we have previously reported, CXCL8 gene, which has five putative HSEs distributed over two 5'flanking regions, exhibited strong HS-induced recruitment of HSF1 to both regions, $-1230 /-1081$ (4 HSEs) and -820/-717 (1 HSE) (Fig 2e).

\subsection{HS exposure differentially affects TNFa-induced CXC chemokine gene expression in A549 cells}

Having determined that at least some of the putative HSEs contained in the 5'-flanking regions of four of the five CXC chemokine genes studied exhibited HS-induced recruitment of HSF1, we analyzed the consequences of these interactions with respect to CXC chemokine gene expression. CXC chemokines are inducible genes and have little or no basal level expression in the absence of pro-inflammatory stimuli in A549 cells. As we previously demonstrated for CXCL8 [24], HS exposure in the absence of pro-inflammatory stimuli 
failed to activate detectable expression of any of the five CXC chemokine genes (data not shown). Following stimulation with TNF $\alpha$ at $37^{\circ} \mathrm{C}$, mRNA levels of all five CXC chemokines increased several fold (Fig 3). Coincident exposure to HS exerted distinct effects on the TNF $\alpha$-induced expression of the five CXC chemokines studied and the magnitude and direction of the effect did not correlate with HSF1 recruitment to the putative HSEs present on their gene promoters. For example, as we have shown earlier [24] treating A549 cells with TNF $\alpha$ for 2, 3, 4, and 6h stimulated 80-, 51-, 26, and 15-fold increases in CXCL8 mRNA levels compared with untreated control cells (Fig 3e). Co-treatment with TNF $\alpha$ and HS did not increase the initial increase in CXCL8 mRNA above levels seen with $\mathrm{TNF} \alpha$ stimulation at $37^{\circ} \mathrm{C}$, but sustained the increased expression so that the levels at the 3 , 4 , and $6 \mathrm{~h}$ time points were 1.8-, 4.6-, and 2.5-fold higher compared with cells exposed to $\mathrm{TNF} \alpha$ alone without HS. (Fig 3e). In contrast to the effects of HS on CXCL8 expression, levels of CXCL5 mRNA, which increased 4-6 fold following stimulation with TNF $\alpha$ at $37^{\circ} \mathrm{C}$, were reduced by about half at all time points analyzed when TNF $\alpha$ treatment was accompanied by HS exposure (Fig 3d). For CXCL1 and CXCL2, mRNA levels increased 2-10-fold after treatment with $\mathrm{TNF} \alpha$ at $37^{\circ} \mathrm{C}$, but coincident exposure to HS had no effect on the TNF $\alpha$-induced expression level of either gene (Fig 3a, b). As expected, the expression of CXCL3, which did not exhibit HS-induced HSF1 recruitment to its 5'-flanking region, was not affected by HS exposure (Fig 3c).

\subsection{HS exposure exerts opposing affects on TNFa-induced secretion of ENA-78 and IL-8 in A549 cells}

To further analyze the effect of heat shock on the CXC chemokines we determined the production and release of ENA-78 (CXCL-5) and IL-8 (CXCL-8). A549 cells were treated with $\mathrm{TNF} \alpha$ and either incubated at $37^{\circ} \mathrm{C}$ for $6 \mathrm{~h}$ or heat shocked for $2 \mathrm{~h}$ and then incubated at $37^{\circ} \mathrm{C}$ for an additional $4 \mathrm{~h}$. Culture supernatants were collected and ENA-78 and IL-8 was measured by ELISA (Fig 4). As expected, both ENA-78 and IL-8 levels were markedly enhanced in culture supernatants of TNF $\alpha$-stimulated A549 cells. However, in the heat shocked TNF $\alpha$-stimulated cells, ENA-78 levels were significantly reduced ( 40\%) (Fig 4a) whereas IL-8 levels were significantly enhanced ( $50 \%)$ (Fig $4 \mathrm{~b})$ in comparison to TNF $\alpha$ stimulated cells incubated only at $37^{\circ} \mathrm{C}$. Thus, similar to the mRNA levels, heat shock exposure had an opposing effect on TNF $\alpha$-induced expression of CXCL-5 and CXCL-8 proteins.

\section{Discussion}

Our results indicate that some but not all of the putative HSEs that were previously identified in five human CXC chemokine gene promoters [21] are capable of binding HSF1 in heat shocked cells. Recruitment of HSF1 to these putative sites varied markedly among the five CXC chemokine genes studied and among multiple putative HSE sequences in the same CXC chemokine gene. Moreover, interaction of HSF1 with each of the CXC chemokine genes analyzed elicits distinct effects, including both positive and negative effects on gene expression.

The first evidence that HSF1 may regulate expression of non-HSP genes was provided by Westwood et al [30] who showed that HS stimulated recruitment of Drosophila HSF to 150 chromosomal loci, which are far more than could be accounted for by the known HSP genes. Recently, Trinklein et al. [31] used ChIP and human promoter microarray analyses to demonstrate that of 182 promoters with putative HSE sequences, HSF1 was recruited to only 94 of these promoters and only 46 among them demonstrated HS-induced activation [31]. The pattern of these results is similar to those of the present study. Of the 24 predicted potential HSEs in the five CXC chemokine genes analyzed, only 10 exhibited HS-induced HSF1 recruitment, and among the four CXCL genes that did exhibit HS-inducible HSF1 
recruitment, only two (CXCL8 and CXCL5) exhibited an effect of HS on TNF $\alpha$-induced gene expression. One important difference between our study and the Trinklein [31] study is the treatment with the pro-inflammatory agonist, TNF $\alpha$, to detect an effect of HS on CXCL gene expression and in its absence, HS alone failed to exert any significant effect on expression of the CXCL genes. These results confirm our previous studies of IL-8 [24] and $\mathrm{TNF} \alpha[14,15]$, indicating multiple distinct mechanisms through which HSF1 may modify gene activation.

Regarding the opposing effects of HS on CXCL8 and CXCL5 gene expression, HSF1 has been found to act both as an activator and a repressor of non-HSP genes. We previously demonstrated that activated HSF1 binds to the HSE sequence present in the TNF $\alpha$ 5'-UTR and represses TNF $\alpha$ transcription $[14,15]$. Others have shown HSF1 to bind to the IL-1 $\beta$ gene promoter to inhibit IL-1 $\beta$ gene expression $[13,20]$. In contrast, HSF1 binds to an HSE sequence in the iNos gene promoter and augments LPS-induced activation of iNos gene expression in heat-shocked murine macrophages [26]. Thus, binding of HSF1 to gene promoters can exert multiple patterns of gene regulation, including: (1) no effect; (2) transcriptional activation; (3) co-activation of transcription in the presence of a proinflammatory stimulus; and (4) transcriptional repression. That the interaction of HSF1 with gene promoters result in different, gene-specific effects underscores the complexity of the mechanisms through which HSF1 regulates transcription. For example, Xie et al. [13] showed that inhibition of IL- $1 \beta$ gene transcription was dependent upon direct interaction and mutual inhibition of HSF1 with the transcription factor, C/EBP- $\beta$ that binds to adjacent sites in the IL-1 $\beta 5^{\prime}$-flanking sequence. Whereas in the case of iNOS, HSF1 binds to a site bordering an E-box in the iNOS gene promoter, which binds transcription factors belonging to the USF family [26]. Thus the spatial orientation of HSF1 binding relative to binding of other transcriptional regulators appear to be critical for HSF1 mediated gene expression. Additionally, post-translational modifications like acetylation, phosphorylation and sumoylation are also key regulators of HSF1 activity [8-12,32-34]. For example, acetylation on certain lysine residues inhibit HSF1 DNA-binding activity [32], whereas phosphorylation of certain serines like S-303/307 inhibit transactivation but not HSF-1 DNA-binding activity $[8,33]$. Conversely, phosphorylation at certain other serines like S-230 was shown to enhance HSF activity [34] indicating the crucial role of these processes in HSF1 regulated gene expression.

It is also important to note that increase in HSF1 transactivating capacity is dependent on both the degree of temperature elevation and the time of exposure [27]. Moreover, inflammatory mediators like arachidonic acid [35], type I interferons [36], or $\mathrm{PGE}_{2}$ [28], all modify activation of HSF1-dependent transcription. Mice deficient in HSF1 exhibit enhanced TNF $\alpha$ expression and increased mortality following experimental endotoxemia [37], providing further evidence for the role of HSF1 in modifying inflammatory responses and immune defenses in vivo. Our present studies also suggest that HSF1 may modify expression of CXC chemokines during stress and inflammation. Our own findings demonstrating enhanced intrapulmonary expression of murine KC (CXCL1), MIP-2 (CXCL2), and LIX (CXCL5/6) in experimental pneumonia, endotoxin aspiration, and pulmonary oxygen toxicity $[23,25]$ support this hypothesis and underscore the importance of understanding the complex biology of HSF1.

In conclusion, we have shown that in heat-shocked A549 cells, HSF1 is recruited to several of the predicted putative HSE-containing flanking sequences in CXC chemokine genes and that binding of HSF1 to each of these CXCL gene promoters has distinct consequences, including transcriptional activation and repression of CXCL gene expression. 


\section{Acknowledgments}

Supported by NIH grants GM069431 (ISS) and GM066855, HL69057 and HL085256 (JDH), and by VA Merit Review grants to JDH and ISS.

\section{Abbreviations}

$\begin{array}{ll}\text { HS } & \text { heat shock } \\ \text { HSP } & \text { heat shock protein } \\ \text { HSF } & \text { heat shock factor } \\ \text { HSE } & \text { heat shock response element } \\ \text { ChIP } & \text { chromatin immunoprecipitation } \\ \text { TNF } & \text { tumor necrosis factor } \\ \text { IL } & \text { interleukin } \\ \text { FRH } & \text { febrile-range hyperthermia } \\ \text { PCR } & \text { polymerase chain reaction } \\ \text { qRT-PCR } & \text { quantitative real-time PCR } \\ \text { ANOVA } & \text { analysis of variance } \\ \text { MANOVA } & \text { multivariate analysis of variance }\end{array}$

\section{References}

[1]. Morimoto RI, Sarge KD, Abravaya K. Transcriptional regulation of heat shock genes. A paradigm for inducible genomic responses. J Biol Chem 1992;267:21987-90. [PubMed: 1429548]

[2]. Morimoto RI, Kline MP, Bimston DN, Cotto JJ. The heat-shock response: regulation and function of heat-shock proteins and molecular chaperones. Essays Biochem 1997;32:17-29. [PubMed: 9493008]

[3]. Morimoto RI. Regulation of the heat shock transcriptional response: cross talk between a family of heat shock factors, molecular chaperones, and negative regulators. Genes Dev 1998;12:3788-96. [PubMed: 9869631]

[4]. Lindquist S. The heat-shock response. Annu Rev Biochem 1986;55:1151-11191. [PubMed: 2427013]

[5]. Feder ME, Hofmann GE. Heat-shock proteins, molecular chaperones, and the stress response: evolutionary and ecological physiology. Annu Rev Physiol 1999;61:243-82. [PubMed: 10099689]

[6]. Sarge KD, Zimarino V, Holm K, Wu C, Morimoto RI. Cloning and characterization of two mouse heat shock factors with distinct inducible and constitutive DNA-binding ability. Genes Dev 1991;5:1902-11. [PubMed: 1717345]

[7]. Perisic O, Xiao H, Lis JT. Stable binding of Drosophila heat shock factor to head-to-head and tailto-tail repeats of a conserved 5 bp recognition unit. Cell 1989;59:797-806. [PubMed: 2590940]

[8]. Pirkkala L, Nykanen P, Sistonen L. Roles of the heat shock transcription factors in regulation of the heat shock response and beyond. Faseb J 2001;15:1118-31. [PubMed: 11344080]

[9]. Sarge KD, Murphy SP, Morimoto RI. Activation of heat shock gene transcription by heat shock factor 1 involves oligomerization, acquisition of DNA-binding activity, and nuclear localization and can occur in the absence of stress. Mol Cell Biol 1993;13:1392-407. [PubMed: 8441385]

[10]. Hietakangas V, Anckar J, Blomster HA, Fujimoto M, Palvimo JJ, Nakai A, et al. PDSM, a motif for phosphorylation-dependent SUMO modification. Proc Natl Acad Sci U S A 2006;103:45-50. [PubMed: 16371476] 
[11]. Hietakangas V, Ahlskog JK, Jakobsson AM, Hellesuo M, Sahlberg NM, Holmberg CI, et al. Phosphorylation of serine 303 is a prerequisite for the stress-inducible SUMO modification of heat shock factor 1. Mol Cell Biol 2003;23:2953-68. [PubMed: 12665592]

[12]. Guettouche T, Boellmann F, Lane WS, Voellmy R. Analysis of phosphorylation of human heat shock factor 1 in cells experiencing a stress. BMC Biochem 2005;6:4. [PubMed: 15760475]

[13]. Xie Y, Chen C, Stevenson MA, Auron PE, Calderwood SK. Heat shock factor 1 represses transcription of the IL-1beta gene through physical interaction with the nuclear factor of interleukin 6. J Biol Chem 2002;277:11802-10. [PubMed: 11801594]

[14]. Singh IS, Viscardi RM, Kalvakolanu I, Calderwood S, Hasday JD. Inhibition of tumor necrosis factor-alpha transcription in macrophages exposed to febrile range temperature. A possible role for heat shock factor-1 as a negative transcriptional regulator. J Biol Chem 2000;275:9841-8. [PubMed: 10734139]

[15]. Singh IS, He JR, Calderwood S, Hasday JD. A high affinity HSF-1 binding site in the 5'untranslated region of the murine tumor necrosis factor-alpha gene is a transcriptional repressor. J Biol Chem 2002;277:4981-8. [PubMed: 11734555]

[16]. Inouye S, Fujimoto M, Nakamura T, Takaki E, Hayashida N, Hai T, et al. Heat shock transcription factor 1 opens chromatin structure of interleukin- 6 promoter to facilitate binding of an activator or a repressor. J Biol Chem 2007;282:33210-7. [PubMed: 17766920]

[17]. Cooper ZA, Ghosh A, Gupta A, Maity T, Benjamin IJ, Vogel SN, et al. Febrile-range temperature modifies cytokine gene expression in LPS-stimulated macrophages by differentially modifying NF- $\{$ kappa $\}$ B recruitment to cytokine gene promoters. Am J Physiol Cell Physiol 2010;298:C171-81. [PubMed: 19846753]

[18]. Cooper ZA, Singh IS, Hasday JD. Febrile range temperature represses TNF-alpha gene expression in LPS-stimulated macrophages by selectively blocking recruitment of Sp1 to the TNF-alpha promoter. Cell Stress Chaperones 2010;15:665-73. [PubMed: 20221720]

[19]. Chen C, Xie Y, Stevenson MA, Auron PE, Calderwood SK. Heat shock factor 1 represses Rasinduced transcriptional activation of the c-fos gene. J Biol Chem 1997;272:26803-6. [PubMed: 9341107]

[20]. Cahill CM, Waterman WR, Xie Y, Auron PE, Calderwood SK. Transcriptional repression of the prointerleukin 1beta gene by heat shock factor 1. J Biol Chem 1996;271:24874-9. [PubMed: 8926278]

[21]. Nagarsekar A, Hasday JD, Singh IS. CXC chemokines: a new family of heat-shock proteins? Immunol Invest 2005;34:381-98. [PubMed: 16136787]

[22]. Singh IS, He JR, Hester L, Fenton MJ, Hasday JD. Bacterial endotoxin modifies heat shock factor-1 activity in RAW 264.7 cells: implications for TNF-alpha regulation during exposure to febrile range temperatures. J Endotoxin Res 2004;10:175-84. [PubMed: 15198852]

[23]. Hasday JD, Garrison A, Singh IS, Standiford T, Ellis GS, Rao S, et al. Febrile-range hyperthermia augments pulmonary neutrophil recruitment and amplifies pulmonary oxygen toxicity. Am J Pathol 2003;162:2005-17. [PubMed: 12759256]

[24]. Singh IS, Gupta A, Nagarsekar A, Cooper Z, Manka C, Hester L, et al. Heat shock co-activates interleukin-8 transcription. Am J Respir Cell Mol Biol 2008;39:235-42. [PubMed: 18367728]

[25]. Rice P, Martin E, He JR, Frank M, DeTolla L, Hester L, et al. Febrile-range hyperthermia augments neutrophil accumulation and enhances lung injury in experimental gram-negative bacterial pneumonia. J Immunol 2005;174:3676-85. [PubMed: 15749906]

[26]. Goldring CE, Reveneau S, Chantome A, Pance A, Fleury C, Hume DA, et al. Heat shock enhances transcriptional activation of the murine-inducible nitric oxide synthase gene. Faseb $\mathrm{J}$ 2000;14:2393-5. [PubMed: 11024011]

[27]. Tulapurkar ME, Asiegbu BE, Singh IS, Hasday JD. Hyperthermia in the febrile range induces HSP72 expression proportional to exposure temperature but not to HSF-1 DNA-binding activity in human lung epithelial A549 cells. Cell Stress Chaperones 2009;14:499-508. [PubMed: 19221897]

[28]. Shah NG, Tulapurkar ME, Singh IS, Shelhamer JH, Cowan MJ, Hasday JD. Prostaglandin E2 potentiates heat shock-induced heat shock protein 72 expression in A549 cells. Prostaglandins Other Lipid Mediat 2010;93:1-7. [PubMed: 20382255] 
[29]. Schefe JH, Lehmann KE, Buschmann IR, Unger T, Funke-Kaiser H. Quantitative real-time RTPCR data analysis: current concepts and the novel "gene expression's CT difference" formula. J Mol Med 2006;84:901-10. [PubMed: 16972087]

[30]. Westwood JT, Clos J, Wu C. Stress-induced oligomerization and chromosomal relocalization of heat-shock factor. Nature 1991;353:822-7. [PubMed: 1944557]

[31]. Trinklein ND, Murray JI, Hartman SJ, Botstein D, Myers RM. The role of heat shock transcription factor 1 in the genome-wide regulation of the mammalian heat shock response. Mol Biol Cell 2004;15:1254-61. [PubMed: 14668476]

[32]. Westerheide SD, Anckar J, Stevens SM Jr. Sistonen L, Morimoto RI. Stress-inducible regulation of heat shock factor 1 by the deacetylase SIRT1. Science 2009;323:1063-6. [PubMed: 19229036]

[33]. Chu B, Soncin F, Price BD, Stevenson MA, Calderwood SK. Sequential phosphorylation by mitogen-activated protein kinase and glycogen synthase kinase 3 represses transcriptional activation by heat shock factor-1. J Biol Chem 1996;271:30847-57. [PubMed: 8940068]

[34]. Holmberg CI, Hietakangas V, Mikhailov A, Rantanen JO, Kallio M, Meinander A, et al. Phosphorylation of serine 230 promotes inducible transcriptional activity of heat shock factor 1 . Embo J 2001;20:3800-10. [PubMed: 11447121]

[35]. Jurivich DA, Sistonen L, Sarge KD, Morimoto RI. Arachidonate is a potent modulator of human heat shock gene transcription. Proc Natl Acad Sci U S A 1994;91:2280-4. [PubMed: 8134388]

[36]. Pica F, Rossi A, Santirocco N, Palamara A, Garaci E, Santoro MG. Effect of combined alpha IFN and prostaglandin A1 treatment on vesicular stomatitis virus replication and heat shock protein synthesis in epithelial cells. Antiviral Res 1996;29:187-98. [PubMed: 8739598]

[37]. Xiao X, Zuo X, Davis AA, McMillan DR, Curry BB, Richardson JA, et al. HSF1 is required for extra-embryonic development, postnatal growth and protection during inflammatory responses in mice. Embo J 1999;18:5943-52. [PubMed: 10545106] 

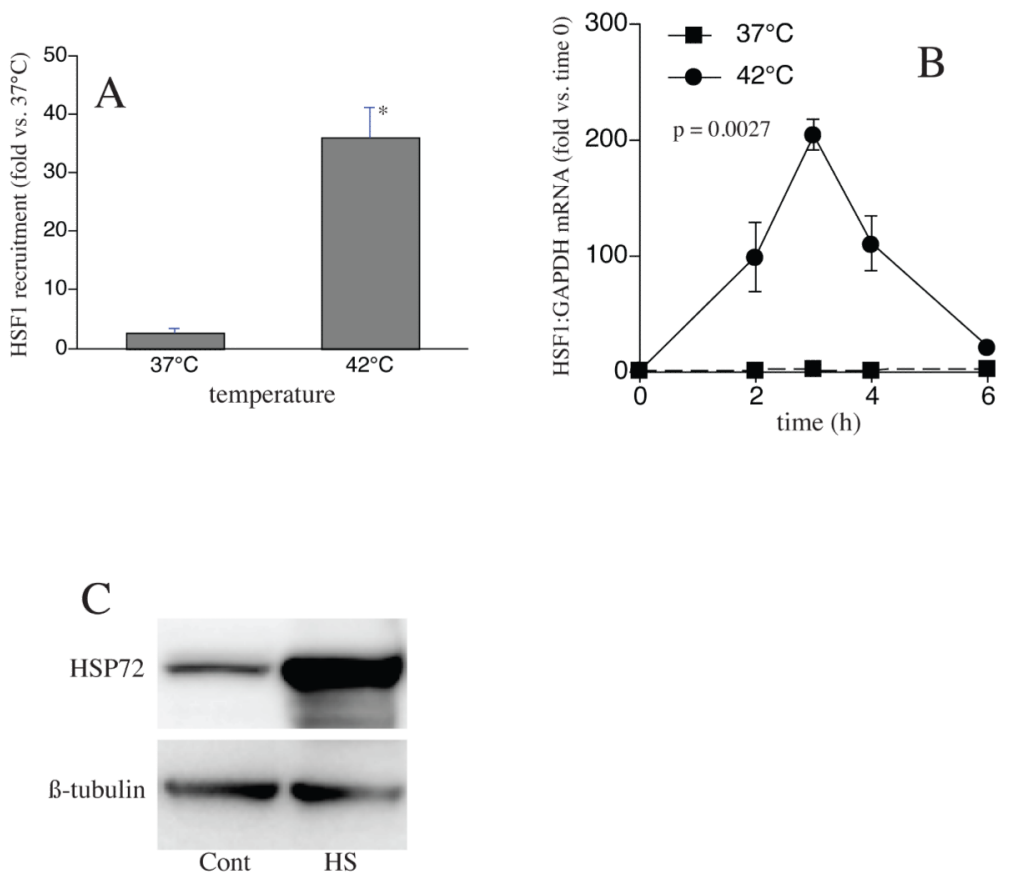

1. Exposing A549 cells to HS recruits HSF1 to the HSP72 gene and induces HSP72 mRNA and protein expression

A. A549 cells were heat-shocked at $42^{\circ} \mathrm{C}$ for $1 \mathrm{~h}$, DNA and protein were cross-linked with formaldehyde, and HSF1 recruitment to the HSP72 gene analyzed by ChIP assay. B. For analysis of HSP72 mRNA levels, A549 cells were heat-shocked at $42^{\circ} \mathrm{C}$ for $2 \mathrm{~h}$ then switched to $37^{\circ} \mathrm{C}$. Total RNA was prepared either immediately after HS or after 1,2 or $4 \mathrm{~h}$ recovery at $37^{\circ} \mathrm{C}$ and analyzed by qRT-PCR for HSP72 and standardized for GAPDH. Data are presented as mean $\pm \mathrm{SE}(\mathrm{n}=4)$, * denotes $\mathrm{p}<0.05$, in comparison to non-heat shocked controls. C. For analysis of HSP72 protein levels, cells were heat shocked at $42^{\circ} \mathrm{C}$ for $2 \mathrm{~h}$ then switched to $37^{\circ} \mathrm{C}$ for $4 \mathrm{~h}$. Cells were lysed and HSP72 protein was analyzed by immunoblot and standardized to $\beta$-tubulin. Figure representative of two independent experiments. 


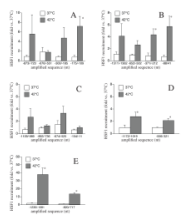

2. HSF1 is recruited to CXC chemokine gene promoters in heat shocked A549 cells A549 cells were heat shocked at $42^{\circ} \mathrm{C}$ for $1 \mathrm{~h}$, and cross-linked chromatin was immunoprecipitated with either anti-HSF1 monoclonal antibody or isotype-specific control IgG (SantaCruz). Primer pairs for the indicated 5'-flanking regions containing HSEs (Table 1) were used to quantify enrichment of HSF1 to the respective sequences. A. CXCL1, B. CXCL2, C. CXCL3, D. CXCL5, and E. CXCL8. Data presented as mean \pm SE (n=4), * denotes $\mathrm{p}<0.05$, in comparison to non-heat shocked controls. 


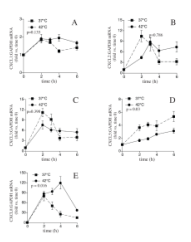

3. TNF $\alpha$-induced CXC chemokine gene expression is differentially modified in heat shocked A549 cells

A549 cells were treated with $\mathrm{TNF} \alpha(1 \mathrm{ng} / \mathrm{ml})$ and incubated either at $37^{\circ} \mathrm{C}$ for up to $6 \mathrm{~h}$ or heat-shocked at $42^{\circ} \mathrm{C}$ for $2 \mathrm{~h}$ and then incubated at $37^{\circ} \mathrm{C}$ for up to $4 \mathrm{~h}$. Total RNA was

prepared either immediately after HS or 1, 2 or 4 h after HS from heat-shocked and corresponding non-heat-shocked controls. qRT-PCR for A. CXCL1, B. CXCL2, C. CXCL3, D. CXCL5, and E. CXCL8 and GAPDH was performed using primer pairs from SA Biosciences. Data presented as mean $\pm \operatorname{SE}(n=4)$. Comparison between heat-shocked and non-heat-shocked cells were analyzed by MANOVA and p-values less than 0.05 was considered statistically significant. 

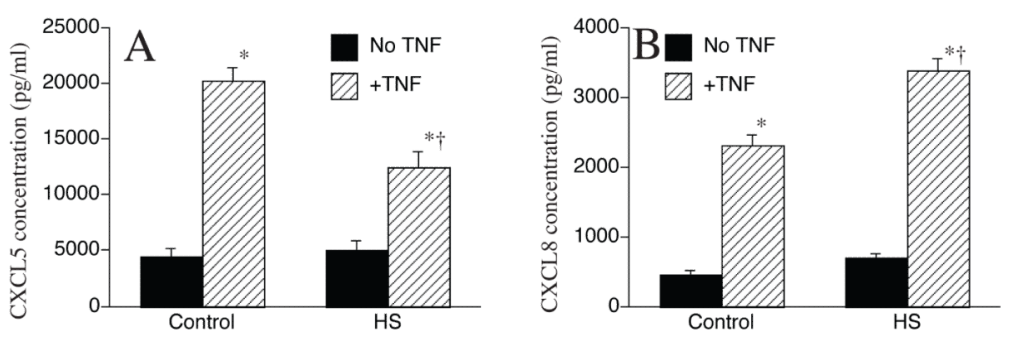

4. TNF $\alpha$-induced ENA-78 and IL-8 production is differentially modified in heat shocked A549 cells

A549 cells were treated with TNF $\alpha(1 \mathrm{ng} / \mathrm{ml})$ and incubated either at $37^{\circ} \mathrm{C}$ for up to $6 \mathrm{~h}$ or heat shocked at $42^{\circ} \mathrm{C}$ for $2 \mathrm{~h}$ and then incubated at $37^{\circ} \mathrm{C}$ for up to $4 \mathrm{~h}$. Cell culture supernatant was collected and ENA-78/CXCL5 (A) and IL-8/CXCL8 (B) was assayed by ELISA. Data presented as mean $\pm \operatorname{SE}(n=8), *$ denotes $\mathrm{p}<0.05$, in comparison to controls, $\dagger$ denotes $\mathrm{p}<0.05$, in comparison to non-heat shocked TNF $\alpha$-stimulated cells. 
Table 1

CXCL genes, number of HSE sites and primer pairs for amplification of the flanking sequences following HSF1 ChIP assays

\begin{tabular}{|c|c|c|c|c|}
\hline CXCL & $\begin{array}{c}\text { Name/ } \\
\text { (Accession No.) }\end{array}$ & $\begin{array}{l}\text { Amplified } \\
\text { Region* }\end{array}$ & Primer Pairs (F/R) & $\begin{array}{l}\text { HSE } \\
\text { sites }\end{array}$ \\
\hline \multirow[t]{4}{*}{1} & \multirow[t]{4}{*}{$\begin{array}{l}\text { Gro1, Gro } \alpha, \text { MGSA, } \\
\text { NAP3 (NM 001511) }\end{array}$} & $-873 /-723$ & $\begin{array}{l}\text { gagtgacaaccagtgccgta/ } \\
\text { gccagggctgtataacatgaa }\end{array}$ & 1 \\
\hline & & $-676 /-551$ & $\begin{array}{c}\text { gttgccaccaaatggaaaac/ } \\
\text { tgctgtctgtgaaagtacagtcc }\end{array}$ & 3 \\
\hline & & $-300 /-185$ & $\begin{array}{l}\text { cctctcaggtggtatcttcagc/ } \\
\text { gcctcgcccttcagagtaac }\end{array}$ & 1 \\
\hline & & $-177 /-19$ & $\begin{array}{l}\text { atcagtggacccccacac/ } \\
\text { accccttttatgcatggttg }\end{array}$ & 1 \\
\hline \multirow[t]{4}{*}{2} & \multirow[t]{4}{*}{$\begin{array}{l}\text { MIP } 2 \alpha, \text { Gro } \beta \\
(\text { NM 002089) }\end{array}$} & $-1511 / 1362$ & $\begin{array}{l}\text { tacttctaacaaccccgtgagg/ } \\
\text { gagatcacttgataaggatgtcagg }\end{array}$ & 2 \\
\hline & & $-652 /-502$ & $\begin{array}{l}\text { gctccactacgttgaaacaca/ } \\
\text { getttaacagtacatgtgtcatctca }\end{array}$ & 2 \\
\hline & & $-371 /-212$ & $\begin{array}{l}\text { cccccggtaaggatgtagc/ } \\
\text { tctttctgccccgaatcc }\end{array}$ & 1 \\
\hline & & $-88 / 41$ & $\begin{array}{l}\text { ctggagctccgggaattt/ } \\
\text { gaggagagctggcaaggag }\end{array}$ & 1 \\
\hline \multirow[t]{4}{*}{3} & \multirow[t]{4}{*}{$\begin{array}{l}\text { MIP2 } \beta, \text { Gro } \gamma \\
(\text { NM 002090) }\end{array}$} & $-1109 /-989$ & $\begin{array}{l}\text { ccagagaaagatcccccagt/ } \\
\text { ttcccactgaaggagcaaac }\end{array}$ & 1 \\
\hline & & $-892 /-736$ & $\begin{array}{l}\text { agcttcagagtgacagccagt/ } \\
\text { cagggetgtataacatgacctct }\end{array}$ & 1 \\
\hline & & $-674 /-525$ & $\begin{array}{c}\text { ggaaaacgtaaacaaggtattctaa/ } \\
\text { tttcggtttagcgttatttca }\end{array}$ & 2 \\
\hline & & $-154 /-11$ & $\begin{array}{l}\text { ctacccgtatccgactccac/ } \\
\text { gatcggcgaaccetttttat }\end{array}$ & 1 \\
\hline \multirow[t]{2}{*}{5} & \multirow[t]{2}{*}{$\begin{array}{c}\text { ENA78 } \\
(\mathrm{NM} \mathrm{002994)}\end{array}$} & $-1172 /-1019$ & $\begin{array}{l}\text { ttcaatttcaggcagcagtg/ } \\
\text { cccagtctgttttccetcaa }\end{array}$ & 1 \\
\hline & & $-495 /-345$ & $\begin{array}{l}\text { ctgcaaggaagacaggaagg/ } \\
\text { gagagaaaaggtggaaccaaa }\end{array}$ & 1 \\
\hline \multirow[t]{2}{*}{8} & \multirow[t]{2}{*}{$\begin{array}{l}\text { IL8, NAF, GCP1 } \\
\text { (NM 000584) }\end{array}$} & $-1230 /-1081$ & $\begin{array}{l}\text { tactatcataagaacccttccttgg/ } \\
\text { ctagcaaaagggatggagtga }\end{array}$ & 4 \\
\hline & & $-820 /-717$ & $\begin{array}{c}\text { tgaagccctcctattcctca/ } \\
\text { gcagaatagacaagtggtactaagaca }\end{array}$ & 1 \\
\hline
\end{tabular}

numbers denote positions relative to transcription start site. 